\title{
The Chemical Compositions of Essential Oils Derived from Cryptocarya alba and Laurelia sempervirens Possess Antioxidant, Antibacterial and Antitumoral Activity Potential
}

\author{
Jorge Touma ${ }^{1}$, Myriam Navarro ${ }^{1}$, Betsabet Sepúlveda ${ }^{2}$, Alequis Pavon ${ }^{3}$, Gino Corsini ${ }^{3}$, \\ Katia Fernández ${ }^{1}$, Claudia Quezada ${ }^{4}$, Angelo Torres ${ }^{4}$, María José Larrazabal-Fuentes ${ }^{5}$ (D), \\ Adrian Paredes ${ }^{5}$ D , Ivan Neira ${ }^{5}$, Matías Ferrando ${ }^{6}$, Flavia Bruna ${ }^{6}$, Alejandro Venegas ${ }^{1}$ \\ and Jessica Bravo $1, *(\mathbb{D}$ \\ 1 Facultad de Medicina, Centro de Investigación Biomédica, Universidad Diego Portales, Ejército 141, \\ Santiago 837007, Chile; jorge.touma@mail.udp.cl (J.T.); Myriam.navarro@mail.udp.cl (M.N.); \\ Katia.fernandez@udp.cl (K.F.); alejandro.venegas@mail.udp.cl (A.V.) \\ 2 Facultad de Ciencias Químicas y Farmacéuticas, Universidad de Chile, Santos Dumont 964, \\ Santiago 8880494, Chile; bsepulveda@ciq.uchile.cl \\ 3 Instituto de Ciencias Biomédicas, Facultad de Ciencias de la Salud, Universidad Autónoma de Chile, \\ Llano Subercaseaux 2801, Santiago 8910060, Chile; apavon@autonoma.cl (A.P.); gcorsini@autonoma.cl (G.C.) \\ 4 Laboratorio de Patología Molecular, Instituto de Bioquímica y Microbiología, Facultad de Ciencias, \\ Universidad Austral de Chile, Valdivia 5110566, Chile; claudiaquezada@uach.cl (C.Q.); \\ angelo.uach.2017@gmail.com (A.T.) \\ 5 Laboratorio Química Biológica, Departamento de Ciencias de los Alimentos y Nutrición, FACSA, \\ Universidad de Antofagasta, Angamos 601, Antofagasta 1270300, Chile; \\ maria.larrazabal@uantof.cl (M.J.L.-F.); adrian.paredes@uantof.cl (A.P.); ivan.neira@uantof.cl (I.N.) \\ 6 Laboratorio de Hormonas y Biología del Cáncer, Instituto de Medicina y Biología Experimental de \\ Cuyo (IMBECU), CONICET CCT-Mendoza UNcuyo 5500, Argentina; MFerrando@gmail.com (M.F.); \\ flabruna@gmail.com (F.B.) \\ * Correspondence: jessica.bravo@mail.udp.cl; Tel.: +56-2-2676-2934
}

Academic Editors: Manuela Pintado and Patrícia Costa

Received: 24 October 2020; Accepted: 24 November 2020; Published: 28 November 2020

\begin{abstract}
Cryptocarya alba (Peumo; CA) and Laurelia sempervirens (Laurel; LS) are herbs native to the Chilean highlands and have historically been used for medicinal purposes by the Huilliches people. In this work, the essential oils were extracted using hydrodistillation in Clevenger apparatus and analyzed by GC-MS to determine their composition. The antioxidant capacity (AC) was evaluated in vitro. The cytotoxicity was determined using cell line cultures both non tumoral and tumoral. The toxicity was determined using the nematode Caenorhabditis elegans. The antimicrobial activity was evaluated against 52 bacteria using the agar disc diffusion method and the minimum inhibitory concentrations (MICs) were determined. The principal compounds found in C. alba essential oil (CA_EO) were $\alpha$-terpineol (24.96\%) and eucalyptol (21.63\%) and were isazafrol (91.9\%) in L. sempervirens essential oil (LS_EO). Both EOs showed antioxidant capacity in vitro. Both EO showed antibacterial activity against bacteria using. LS_EO showed more inhibitory effect on these cell lines respect to CA_EO. Both EOs showed toxicity against the nematode C. elegans at $3.12-50 \mathrm{mg} / \mathrm{mL}$. The essential oils of CA and LS have an important bioactive potential in their antioxidant, antibacterial and cytotoxicity activity. Both essential oils could possibly be used in the field of natural medicine, natural food preservation, cosmetics, sanitation and plaguicides among others.
\end{abstract}

Keywords: essential oil; Cryptocarya alba; Laurelia sempervirens; chemical composition; antioxidant; cytoxicity; toxicity; antimicrobial 


\section{Introduction}

Cryptocarya alba and Laurelia sempervirens essential oil (EO) plant species used by the Huilliche people of Chile for wound treatment and associated infections, were evaluated against bacterial and fungal human pathogens [1]. Essential oils exhibit a wide range of bioactivities. The antimicrobial activity has played a key role in the utilization of these EOs for the treatment of various human diseases.

Cancer is an important cause of morbidity and mortality worldwide [2]. The increase of the incidence indicates that 1:8 men and 1:10 women will develop this multifactorial disease in a lifetime [2]. Due to the aforementioned, the research for alternative and complementary treatments of cancerous diseases still motivates the search for new antitumoral agents [3]. The EOs obtained from diverse plants are able to increase the efficacy of commonly used chemotherapy drugs, having also shown pro-immune functions when administered to cancer patients [4]. It has been reported that the EOs may interfere in various signaling pathways in cancerous cells and may exert anti-mutagenic, anti-proliferative, antioxidant and detoxifying effects [3]. The MCF-7 line is one of the most described cell lines in the literature for testing antitumor activity of natural bioactive products. The cytotoxic effects on MCF-7 cell line treated with EOs from plants of the genus Cryptocarya [5,6] and Laurelia [7] had previously been reported.

In Chile, research on antimicrobial compounds obtained from native plants has yielded some positive results in the antimicrobial activity [1]. Moreover, Bittner [8] has evaluated the fungistatic activity of EO extracted from CA_EO and LS_EO against fungi such as Rhizoctonia solani Kühn (Donk) and Fusarium oxysporum Schltdl. Additionally, Avello [9] evaluated the antifungal activity of EOs extracted from canelo, queule, bailahuén and culen against other phytopathogenic fungi, such as Botritys cinerea, Fusarium oxysporum and Aspergillus niger. Additionally, we have identified the major active compounds as well as evaluated the effects of the CA_EO against $N$. ceranae and its potential use for the control of nosemosis disease [10].

The aim of this work was to evaluate the chemical composition of the EOs extracted from C. alba and L. sempervirens and their antioxidant capacity, cytotoxicity activity and antibacterial potential.

\section{Results}

\subsection{Composition}

The sample compositions obtained by hydrodistillation using the Clevenger-type apparatus Table 1 indicated that the C. alba essential oil (CA_EO) contained 14 compounds, while the L. sempervirens essential oil (LS_EO) contained 6 compounds. The highest yielding compounds in CA were $\alpha$-terpineol (24.96\%), eucalyptol (21.63\%), and $\beta$-phellandrene (14.84\%) and the highest yielding compounds in LS were isazafrol $(91.9 \%)$, limonene $(5.3 \%)$, and $O$-cimene $(1.3 \%)$.

Table 1. Compounds from GC-MS analyses of (A) C. alba and (B) L. sempervirens EOs, the respective calculated Kovats index (KI cal) and from the Kovats index literature (KI lit).

\begin{tabular}{ccccccccc}
\hline $\begin{array}{c}\text { Fraction } \\
\text { Number }\end{array}$ & $\begin{array}{c}\text { Retention Time } \\
(\mathbf{m i n})\end{array}$ & CAS & KI Cal & KI Lit & {$\left[\mathbf{M}^{+}\right]$} & Fragment & Name \\
\hline \multicolumn{7}{c}{} & \multicolumn{7}{c}{ (A) C. Alba Essential Oil } \\
\hline 1 & 14.5 & $99-83-2$ & - & 1007 & 136 & $99(100) 91(38) 77(33)$ & 0.71 & D-phellandrene \\
2 & 14.8 & $7785-70-8$ & 1025 & 939 & 136 & $93(100) 92(41) 79(19)$ & 3.88 & $1 R-\alpha$-pinene \\
3 & 15.7 & $79-92-5$ & 1041 & 953 & 136 & $93(100) 121(66) 41(38)$ & 0.19 & Camphene \\
4 & 17.0 & $555-10-2$ & 1081 & 1035 & 136 & $93(100) 43(38) 121(23)$ & 14.84 & $\beta$-phellandrene \\
5 & 17.3 & $18172-67-3$ & 1012 & 981 & 136 & $93(100) 41(69) 69(43)$ & 4.18 & L- $\beta$-pinene \\
6 & 19.5 & $586-62-9$ & 1085 & 1088 & 136 & $93(100) 121(98) 136(72)$ & 0.92 & Terpinolene \\
7 & 19.9 & $527-84-4$ & 1067 & 1014 & 136 & $93(100) 135(75) 121(46)$ & 3.99 & 0 -cimol \\
8 & 20.1 & $5989-54-8$ & 1050 & 1031 & 136 & $68(100) 93(57) 39(36)$ & 3.41 & Limonene \\
9 & 20.3 & $470-82-6$ & 1013 & 1030 & 154 & $139(100) 154(85) 27(28)$ & 21.63 & Eucalyptol \\
10 & 21.7 & $99-85-4$ & 1035 & 1057 & 136 & $93(100) 91(35) 136(33)$ & 2.67 & $\gamma$-terpinene \\
11 & 24.3 & $54410-94-5$ & 1053 & 1116 & 170 & $68(100) 57(43) 41(39)$ & 1.34 & 3 methyl 3 butenyl \\
12 & 26.6 & $562-74-3$ & 1079 & 1177 & 154 & $71(100) 111(53) 43(45)$ & 1.72 & 4 -terpineol \\
\hline
\end{tabular}


Table 1. Cont

\begin{tabular}{|c|c|c|c|c|c|c|c|c|}
\hline $\begin{array}{l}\text { Fraction } \\
\text { Number }\end{array}$ & $\begin{array}{l}\text { Retention Time } \\
\text { (min) }\end{array}$ & CAS & KI Cal & KI Lit & {$\left[\mathbf{M}^{+}\right]$} & Fragment & $\%$ & Name \\
\hline 13 & 27.2 & $98-55-8$ & 1009 & 1189 & 154 & $59(100) 93(53) 43(45)$ & 24.96 & $\alpha$ - terpineol \\
\hline 14 & 33.3 & 17699-05-7 & 1580 & 1434 & 204 & 93 (100) 119 (86) 41 (51) & 2.88 & $\alpha$-bergamolene \\
\hline 15 & 34.8 & 339154-91-5 & 1575 & 1430 & 204 & $121(100) 93(69) 41(63)$ & 0.99 & $\gamma$-elemene \\
\hline 16 & 35.3 & $483-77-2$ & 1515 & 1523 & 202 & $132(100) 159(98) 131(51)$ & 1.36 & calamenene \\
\hline 17 & 38.1 & $473-15-4$ & 1733 & 1645 & 223 & 207 (100) 125 (19) 153 (15) & 1.49 & $\beta$-eudesmol \\
\hline \multicolumn{9}{|c|}{ (B) L. Sempervirens Essential Oil } \\
\hline 1 & 12.0 & $138-86-3$ & - & 1036 & 136 & $93(100) 68$ (67) 136 (63) & 5.3 & Limonene \\
\hline 2 & 12.8 & $13877-91-3$ & 1000 & 1023 & 136 & $93(100) 91(57) 41(54)$ & 1.3 & O-cimene \\
\hline 3 & 20.3 & $120-58-1$ & 1000 & - & 162 & $162(100) 104(31) 78(13)$ & 91.9 & Isozafrol \\
\hline 4 & 24.7 & $489-39-4$ & 1148 & - & 204 & $41(100) 161(92) 91(86)$ & 0.5 & Aromadendrene \\
\hline 5 & 25.2 & $23986-74-5$ & 1500 & 1499 & 204 & $161(100) 105(79) 41(62)$ & 0.7 & Germacrene D \\
\hline 6 & 25.6 & 339154-91-5 & - & 1433 & 204 & $121(100) 93(69) 41(63)$ & 0.3 & $\gamma$-elemene \\
\hline
\end{tabular}

\subsection{Antioxidant Capacity}

The antioxidant potential of CA and LS EOs was evaluated using the following complementary techniques: total Polyphenols contents, FRAP and radical scavenger DPPH and ABTS methods. The results are showed in Table 2 . The EOs showed significant antioxidant activity with variability in the different methods used.

Table 2. Antioxidant capacity of C. alba and L. sempervirens essential oils.

\begin{tabular}{ccccc}
\hline Essential Oils & Total Phenols $^{\mathbf{a}}$ & FRAP $^{\mathbf{b}}$ & IC $_{\mathbf{5 0}}$ DPPH $^{\mathbf{c}}$ & IC $_{\mathbf{5 0}}$ ABTS $^{\mathbf{c}}$ \\
\hline L. sempervirens & $63.7 \pm 10.7$ & $229.8 \pm 11.1^{*}$ & $417.8 \pm 5.8^{+++}$ & $401.2 \pm 8.7^{+++}$ \\
\hline C. alba & $163.6 \pm 10.7^{* *}$ & $166.8 \pm 27.9$ & $492.7 \pm 11.1^{+++}$ & $203.0 \pm 12.8^{* *++++}$ \\
\hline Trolox & - & - & $11.7 \pm 2.1$ & $35.6 \pm 1.5$ \\
\hline
\end{tabular}

All values were expressed as Means \pm SEM $(n=4)$. ${ }^{\text {a }}$ expressed in $\mathrm{mg}$ Gallic acid equivalent/g essential oil.

$\mathbf{b}^{\mathbf{b}}$ expressed in $\mathrm{mg}$ Trolox equivalent/g essential oil. ${ }^{c}$ expressed in $\mu \mathrm{g} / \mathrm{mL} .{ }^{*} * *$ significantly different $(p<0.5$ and $p<0.01) .^{+++}$significantly different respect to control $(p<0.001)$.

\subsection{Antimicrobial Activity}

The antimicrobial activity of the CA_EO and LS_EO are shown in Table 3. The CA_EO was the most effective against $S$. aureus, E. coli, C. albicans and $H$. pylori with inhibition zones of 25, 8, and $15 \mathrm{~mm}$ (Figure 1), respectively and complete inhibition at the same concentration against $H$. pylori. The essential oil was shown to have antimicrobial activity against both Gram-positive and Gram-negative bacteria. Antimicrobial activity against $E$. coli was slightly less than that against $S$. aureus and C. albicans $(p<0.05)$ at the same concentration. The MICs of the CA_EO against the bacteria mentioned above were 19.0, 36.0, 31.0, and $30.0 \mu \mathrm{g} / \mathrm{mL}$ respectively, and LS_EO against the bacteria mentioned above were $64.0 \mu \mathrm{g} / \mathrm{mL}$.

Table 3. The MIC values of CA_EO, LS_EO and their major components against clinical isolates of H. pylori, S. aureus, E. coli and C. albicans.

\begin{tabular}{ccccc}
\hline $\begin{array}{c}\text { EO or Its } \\
\text { Purified Component }\end{array}$ & $\begin{array}{c}\text { MIC }(\mu \mathrm{g} / \mathrm{mL}) \\
\text { H. } \text { pylori }\end{array}$ & $\begin{array}{c}\text { MIC }(\mu \mathrm{g} / \mathrm{mL}) \\
\text { S. aureus }\end{array}$ & $\begin{array}{c}\text { MIC }(\mu \mathrm{g} / \mathrm{mL}) \\
\text { E. coli }\end{array}$ & $\begin{array}{c}\text { MIC }(\mu \mathrm{g} / \mathrm{mL}) \\
\text { C. albicans }\end{array}$ \\
\hline CA_EO & 30 & 19 & 36 & 31 \\
\hline$\alpha$-terpineol & 27 & 32 & 16 & 16 \\
\hline$\beta$-phellandrene & 30 & 32 & 32 & 32 \\
\hline Eucalyptol & 30 & 32 & 32 & 32 \\
\hline LS_EO & 64 & 64 & 64 & 64 \\
\hline Limonene & 32 & 32 & 64 & 64
\end{tabular}

The ANOVA analysis including the Tukey test did not show significant differences between the $\beta$-phellandrene and eucalyptol purified compounds. The values were an average of 7 isolates for H. pylori and 15 isolates for the other species. The whole experiment was done in triplicate. 


\section{Zone inhibition (mm)}

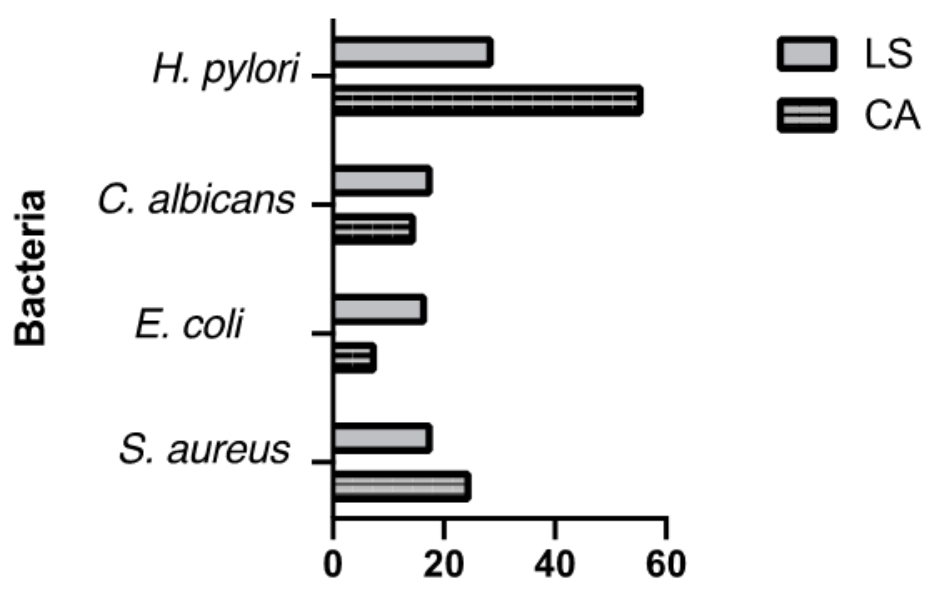

Figure 1. Zone of Inhibition ( $\mathrm{mm}$ ) resulting from CA (Cryptocarya alba) and LS (Laurelia sempervirens) EOs obtained by hydrodistillation in a Clevenger-type apparatus.

\subsection{Cytotoxicity Activity}

Both CA and LS EOs present selective inhibitory activity on epithelial tumor cells. Figure 2, Figure S3, Figure 3a-d, Figures 4 and 5.

a.

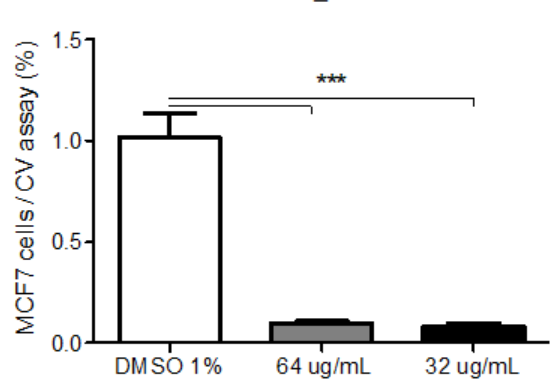

c.

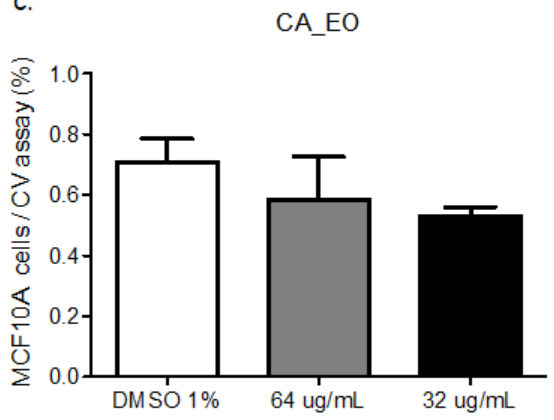

b.

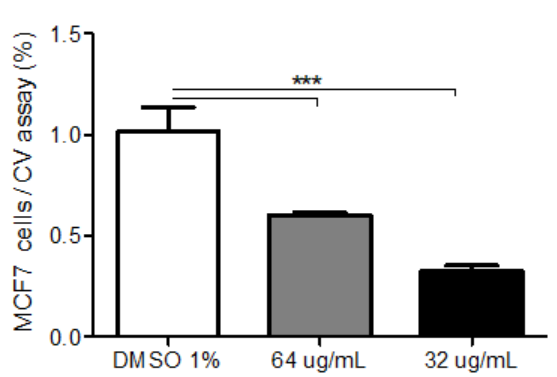

d.

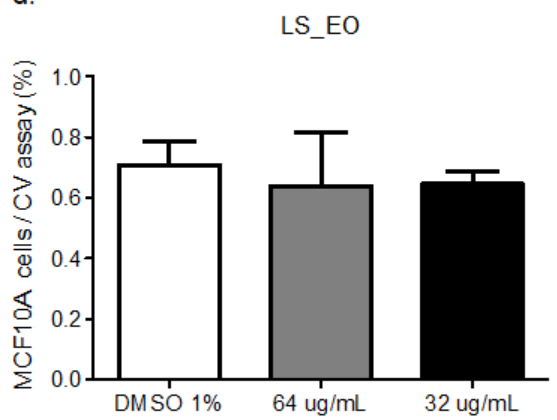

Figure 2. Dose-response curve of the human epithelial mammary tumor cell line MCF-7 (a,b) and epithelial mammary non-tumoral cell line MCF10A(c,d) treated with CA or LS EOs. The graph bar corresponds to the proliferation of MCF-7 treated with the EOs at different concentrations versus control (DMSO 1\%) for $48 \mathrm{~h}$, evaluated by CV assay at $570 \mathrm{~nm}$. Three independent trials were performed, in triplicate, for each treatment and concentration. ${ }^{* * *} p<0.001$. 


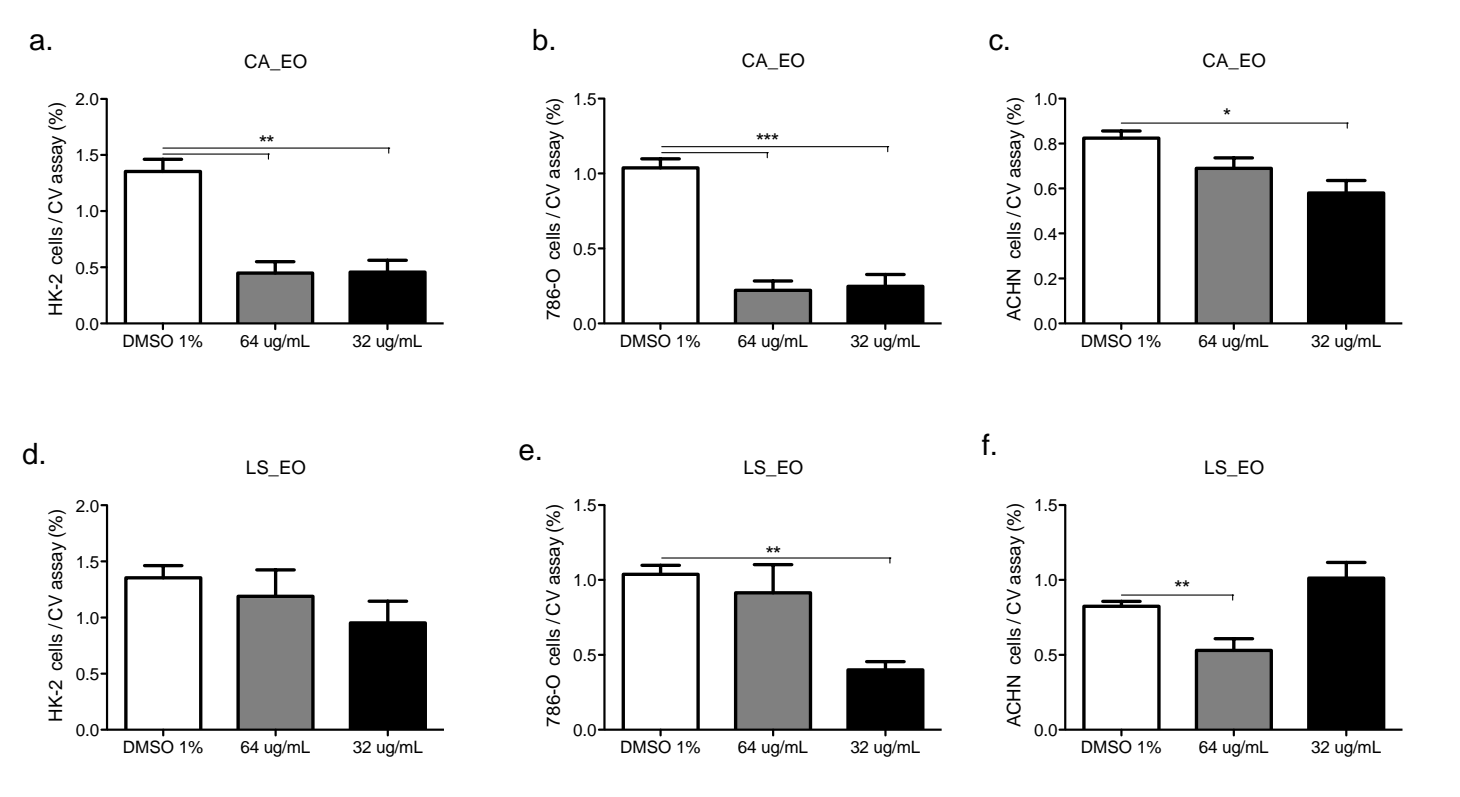

Figure 3. Dose-response curve of the human epithelial renal non-tumor cell line (HK2, a-d) and tumor cells line $((786-\mathrm{O}, \mathbf{b}-\mathbf{e})$ and $(\mathrm{ACHN}, \mathbf{c}-\mathbf{f}))$, treated with CA or LS EOs. The graph bar corresponds to the proliferation of $\mathrm{Hk} 2,786-\mathrm{O}$ and $\mathrm{ACHN}$, treated with the EOs at different concentrations versus control (DMSO 1\%) for $48 \mathrm{~h}$, evaluated by CV assay at $570 \mathrm{~nm}$. Three independent trials were performed, in triplicate, for each treatment and concentration. ${ }^{*} p<0.05,{ }^{* *} p<0.005,{ }^{* * *} p<0.001$.

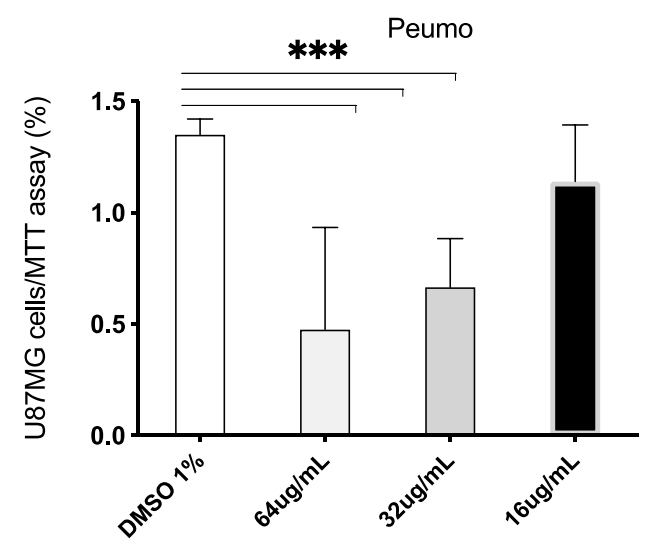

(a)

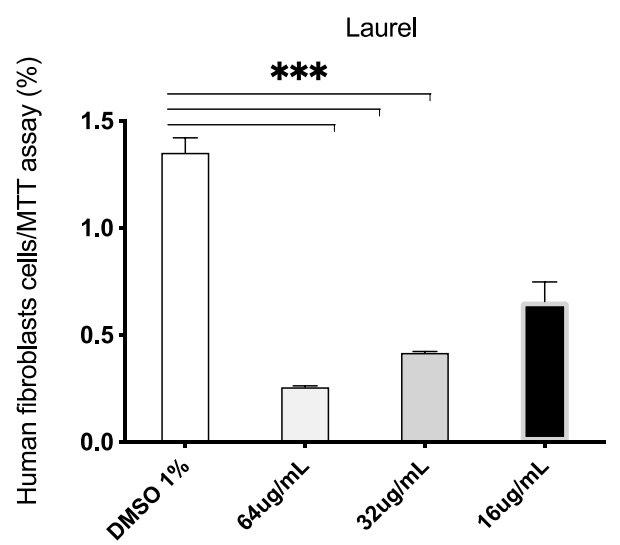

(b)

Figure 4. Dose-response curve of human glioblastoma cells tumor cell line U87MG treated with Cryptocarya alba (Peumo; CA); Laurelia sempervirens (Laurel; LS) EOs. The graph bar corresponds to the proliferation of U87GMtreated with the Eos (a. Peumo) and (b. Laurel), at different concentrations versus control (DMSO 1\%) for $48 \mathrm{~h}$, evaluated by MTT assay at $570 \mathrm{~nm}$. Three independent trials were performed, in triplicate, for each treatment and concentration. ${ }^{* * *} p<0.001$. 


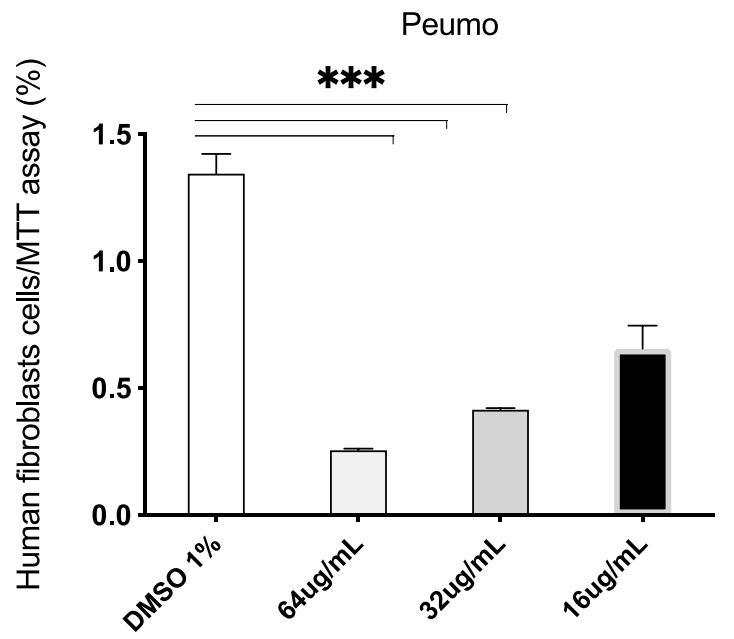

(a)

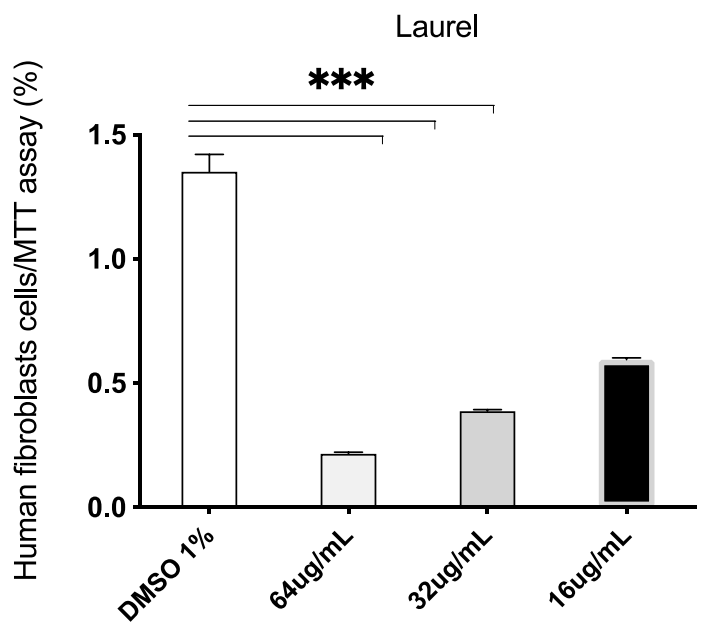

(b)

Figure 5. Dose-response curve of human fibroblasts cells treated with Cryptocarya alba (Peumo; CA); Laurelia sempervirens (Laurel; LS) EOs. The graph bar corresponds to the proliferation of fibroblasts cells treated with the Eos (a. Peumo) and (b. Laurel), at different concentrations versus control (DMSO 1\%) for $48 \mathrm{~h}$, evaluated by MTT assay at $570 \mathrm{~nm}$. Three independent trials were performed, in triplicate, for each treatment and concentration. ${ }^{* *} p<0.001$.

\subsection{Toxicity}

CA_EO showed low or no toxicity against $C$. elegans (Figure 6) while LS_EO showed toxicity in all the concentrations evaluated, with $100 \%$ mortality, both at 24 and 48 h. CA_EO was toxic at $24 \mathrm{~h}$ at 50 with $100 \%$ mortality.

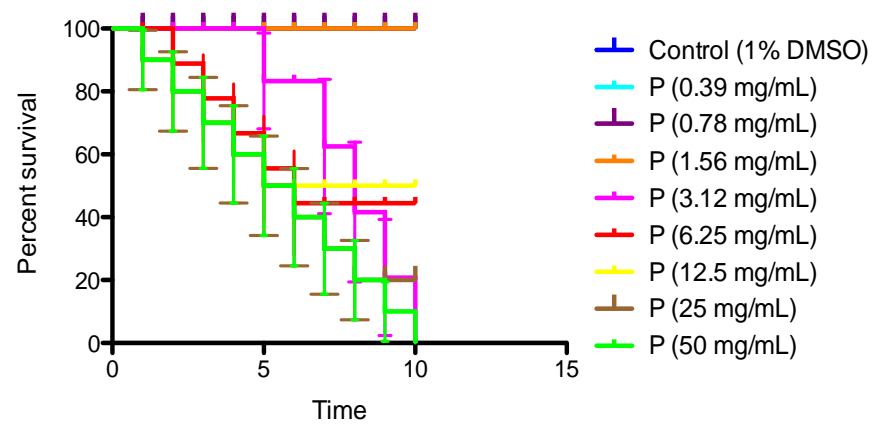

(A)

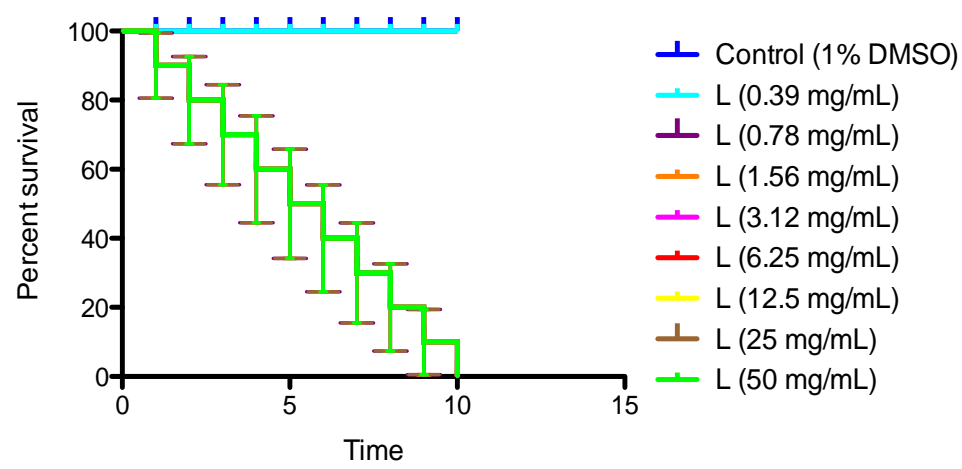

(B)

Figure 6. (A) Percent survival of P (Peumo, C. alba) and (B) L (Laurel, L. sempervirens) EOs against C. elegans. 


\section{Discussion}

The EO yields obtained using hydrodistillation by the HD process were $0.6 \%$ for CA and $1.08 \%$ for LS. These differ from those reported by other authors who extracted the EOs by hydrodistillation from the same herbs. For LS, the range was between $2.79 \%$ and $6.28 \%$ [8], while for CA and LS values were $0.76 \%$ and $0.7 \%$ respectively [9].

The sample compositions obtained by HD using the Clevenger-type apparatus (Table 1) indicated that the CA_EO contained 14 compounds, while the LS_EO contained 6 compounds. The highest yielding compounds in CA_EO were $\alpha$-terpineol (24.96\%), eucalyptol (21.63\%), and $\beta$-phellandrene $(14.84 \%)$ and the highest yielding compounds in LS were isazafrol (91.9\%), limonene (5.3\%), and O-cimene $(1.3 \%)$.

Zapata [11], reported that the LS_EO extracted by HD contained 16 compounds with safrole (82.4\%) and limonene $(7.76 \%)$ being the highest [11]. The CA_EO analysis CG-MS contained 6 compounds where 1-terpinen-4-ol (28.19\%) and $\beta$-terpineno (23.08\%) constituted the majority. The LS_EO contained 12 compounds where safrol (31.43\%) and (1S)- $\alpha$-pineno (27.91\%) constituted the majority [9].

In the current study, the differences in the yield and composition of the CA and LS_EOs compared to those in the literature, could be due to both the extraction method and the collection time [12]. The chemical composition of the oils affects their bioactivity [13], even though their bioactivity should not be attributed to a particular compound [14]. Biological effects are the result of a synergism of all molecules contained in an EO even if it is possible that the activity of the main component is modulated by other minor molecules. The activity of the isolated constituents, however, is also notable [15]. Previously we demonstrated the CA_EO antifungal activity against Nosema ceranae [10]. Some of the compounds found in this work such as eucalyptol, (one of the major compounds in CA_EO) has been reported in other EOs included Acantholippia deserticola and demonstrated inhibition of $E$. coli [16]. Eucalyptol was ascertained in P. boldus and L. philippiana EO antifungal activity against Fusarium oxysporum Schltdl [8].

The total phenol content in the EOs was determined by the Folin-Ciocalteu spectrometric method. The amount of total content of phenols for both oils was moderate with a value of $63.7 \pm 10.7$ for EO_LS and significantly higher $(p<0.01) 163.6 \pm 10.7 \mathrm{mg}$ Gallic acid equivalent/g for CA_EO respectively. The FRAP method is based on the reduction of the $\mathrm{Fe}^{3+}-\mathrm{TPTZ}$ (iron-tripyridyltriazine) complex, to $\mathrm{Fe}^{2+}-\mathrm{TPTZ}$, that is, it measures the capacity of the $\mathrm{EO}$ to reduce $\mathrm{Fe}^{3+}$ to $\mathrm{Fe}^{2+}$. For this assay the $\mathrm{EO}$ of LS was significantly more effective $(p<0.05)$ in the reduction of the complex $\mathrm{Fe}^{3+}$ with a value of $229.8 \pm 11.1 \mathrm{mg}$ Trolox equivalent/g EO, while the CA_EO presents values of $166.8 \pm 27.9 \mathrm{mg}$ Trolox equivalent/g EO respectively. Two complementary techniques were used to evaluate the potential free radical scavenger of EOs using the $\mathrm{DPPH}$ and $\mathrm{ABTS}$ radicals. When comparing the $\mathrm{IC}_{50}$ values, it was observed that both EOs exhibit moderate DPPH radical scavenging activity. The values for CA_EO was $417.8 \pm 5.8 \mu \mathrm{g} / \mathrm{mL}$ and $492.7 \pm 11.1 \mu \mathrm{g} / \mathrm{mL}$ for LS_EO. Both oils scavenged the DPPH radical in a concentration-dependent manner. Neither of the two oils was as effective as the Trolox antioxidant $\left(\mathrm{IC}_{50}=11.7 \pm 2.1 \mu \mathrm{g} / \mathrm{mL}\right)$. The CA_EO showed a significantly $(p<0.01)$ greater ability to inhibit the ABTS radical compared to the LS_EO with $\mathrm{IC}_{50}$ values of $203.0 \pm 12.8 \mu \mathrm{g} / \mathrm{mL}$ and $401.2 \pm 8.7 \mu \mathrm{g} / \mathrm{mL}$ respectively (Table 2). Both EOs showed a significantly $(p<0.001)$ lower inhibitory activity than Trolox $\left(\mathrm{IC}_{50}=35.6 \pm 1.5 \mu \mathrm{g} / \mathrm{mL}\right)$. While no phenolic compounds were found and considering that CA_EO has a higher antioxidant potential than EO_LS, this could be attributed to compounds such as $\alpha$-terpineol, $\gamma$-terpinene, $\beta$-phellandrene whose activity had been previously described by Amorati [17]. It could be inferred that the antioxidant activity of the Eucalyptus globulus oil is mainly due to the presence of its major compounds, namely 1,8-cineole (63.8\%) [11]. Eucalyptol (1,8-cineole) showed various degrees of reducing power, radical scavenging and chelating capacity, in addition to its DNA-protective capacity [11]. Moreover, the high value of the reducing power indicated that the EOs components are able to act as electron donors and reduce the oxidized intermediate of lipid peroxidation so that they can act as primary and secondary antioxidants [13]. 
Total antioxidant activities of the EOs cannot be evaluated by any single method due to the complex nature of phytochemical composition [18]. Two or more methods should always be employed in order to evaluate the total antioxidative effects. In this sense, the CA_EO, showed a higher antioxidant activity, compared to that of LS_EO obtained with FRAP, DPPH or ABTS methods [19]. This may be due in part to the complexity of the chemical composition. The antioxidant activity shown by CA_EO can be explained by its greater composition in terpenes with their conjugated hexadiene structure (35\% of its composition), in comparison to the content of $14 \%$ of compounds with the same carbon nucleus for the LS_EO. It has been shown that the compounds present in the CA_EO such as d-phellandrene $(0.71 \%)$, $\beta$-phellandrene $(14.84 \%) \gamma$-terpinene $(2.67 \%), \alpha$-terpinene $(24.96 \%)$ and limonene $(3.41 \%)$, act through a mechanism of autooxidation, trapping free radicals efficiently [12]. This higher antioxidant activity is also due to the fact that the CA_EO has in its composition hydroxylated terpenes such as $\beta$-eudesmol (1.49\%), 4-terpineol (1.72\%) and the second major component $\alpha$-terpineol $(24.29 \%)$. On the other hand, the LS_EO does not present hydroxylated terpenes and only 5.3\% of limonene. Although phenolic aromatic compounds were not identified in both oils, there are reports of other EOs whose absence of this type of compound has presented a higher antioxidant capacity comparable to the synthetic antioxidant BHT $[17,19,20]$.

The CA_EO was the most effective against S. aureus, E. coli, C. albicans and H. pylori with inhibition zones of 25, 8, and $15 \mathrm{~mm}$ (Figure 1) respectively. Additionally, the CA_EO showed a complete inhibition at the same concentration against $H$. pylori and showed antimicrobial activity against both Gram-positive and Gram-negative bacteria. At the same concentration antimicrobial activity against E. coli was slightly lower than that against $S$. aureus and C. albicans $(p<0.05)$. The MICs of the CA_EO against the bacteria mentioned above were 19.0, 36.0, 31.0, and $30.0 \mu \mathrm{g} / \mathrm{mL}$ respectively (Table 3). The MIC for LS_EO against the above-mentioned bacteria was $64.0 \mu \mathrm{g} / \mathrm{mL}$. The chemical composition of CA_EO which is primarily composed of $\alpha$-terpineol (27.96\%), eucalyptol (21.63\%), and $\beta$-phellandrene (14.84\%). On the other hand, LS_EO which is composed by limonene (5.3\%), showed strong antimicrobial activity against $S$. aureus and H. pylori.

The biological activity on the major monoterpenes reported for CA_EO components, has been previously described, as noted below. For instance, a study showed that a protective effect of standardized Pistacia atlantica EO against ethanol-induced gastric ulcers; $\alpha$-pinene being the main agent responsible for the Helicobacter pylori antibacterial activity [21]. In a study about several EOs (C. alba was not included) and their effects on $H$. pylori, eugenol was detected in the EOs isolated from Cinnamomum zeylanicum and Eugenia caryophyllus [22]. Eucalyptol was also found in Satureja montana and also in Eucalyptus globulus. In addition to this, carvacrol (an $\alpha$-terpineol isomer), was present in C. zeylanicum and S.montana. Little is known regarding the mechanisms of action of these compounds. For instance, carvacrol, has a hydroxyl group with the potential capability to act as a metal chelator of transmembrane carriers for monovalent cations thus affecting membrane potential [23]. Therefore, this compound potentially destroys the proton motive force and inhibits some enzymes and other essential macromolecules involved in this phenomenon [24]. With the above-described, one could associate the monoterpene $\alpha$-terpineol and eucalyptol with the CA_EO antibacterial activity. With this background, the antibacterial activity could be attributed to CA_EO monoterpenes such as $\alpha$-terpineol and eucalyptol.

Regarding the lower MIC or bacteriolytic activity values reported against $H$. pylori for some EOs such as $0.01 \%(v / v)$ dilution for lemongrass (Cymbopagon citratus) oil [25] and the MIC value $2 \mu \mathrm{g} / \mathrm{mL} \mathrm{of}$ EO from the Peruvian native plant Minthostachys mollis [26]. The MCB values for carrot and lemongrass oil are 0.02 and $0.04 \mu \mathrm{g} / \mathrm{mL}$ respectively [22]. These numbers are not quite comparable given that the value described here for C. alba EO $0.1 \%(v / v)$ dilution and $\mathrm{MIC}=29 \mu \mathrm{g} / \mathrm{mL}$, (Table 3) is close to the range of those oils previously mentioned as values required to block $H$. pylori growth. This implies that CA_EO is a promising candidate to fight H. pylori infections. For further comparison with other compounds also see Table 3. In addition to this antibacterial activity, the CA_EO has been used in, 
traditional medicine and an insect repellent. Other studies have verified antifungal properties against Penicillium sp. and Fusarium oxysporum [9] as well as activity against other fungus species [27,28].

In order to evaluate the selective cytotoxicity and the antitumoral activity of the EOs, mammary tumor cell line MCF-7 and the non-tumor cell line MCF10A, were incubated with CA_EO and LS_EO at different concentrations and a proliferation CV assay was performed [29]. CA_EO and LS_EO significantly inhibited the proliferation of mammary tumor MCF-7 cells at 64 and $32 \mathrm{ug} / \mathrm{mL}$ concentrations, being more evident with CA_EO. Conversely, in the MCF10A non-tumoral cells no significant differences were found among the treatments, irrespective of the concentration (Figure 2). We found that the MCF-7 epithelial cells showed an inhibited proliferation when treated with CA_EO at different concentrations (64 to $16 \mathrm{ug} / \mathrm{mL}$ ). Minor concentrations of $8 \mathrm{ug} / \mathrm{mL}$ did not show any effects (Supplementary Figure S3). The antitumoral effect was maintained in the other tumor epithelial cells. The human epithelial renal cells (HK-2, 786-O and ACHN) were exposed to the EOs and a dose-response curve was performed. In contrast to the effect observed in non-tumoral mammary cells, the CA_EO showed an inhibitory effect on proliferation of non-tumor renal cell HK-2 (Figure 3a), while LS_EO did not show an inhibitory effect on the proliferation of this cell line (Figure 3d). Regarding the primary tumor $(786-\mathrm{O})$ and metastatic site $(\mathrm{ACHN})$ renal cell lines, treatment with both EOs demonstrated a significant inhibition on cell viability and proliferation (Figures $3 b-c$ and $3 d-e$ respectively). The CA and LS EOs demonstrated a significant inhibition on cell viability and proliferation at $64 \mathrm{ug} / \mathrm{mL}$ in human glioblastoma cells tumor cell line U87MG and human fibroblast cells (Figures 4 and 5, respectively). The LS_EO showed a greater inhibitory effect on these cell lines compared to CA_EO. This could be attributed to the presence of limonene which has been previously described for its antitumoral potential, inhibited the growth of lung cancer cells and suppressed the growth of transplanted tumors in nude mice [30]. Limonene exerted its effects by up-regulation of BAX, cytochrome c release, caspase-3, caspase-9, TGF- $\beta$, and down-regulation of anti-apoptotic Bcl-2 [31]. On the other hand, POH also up-regulates Bak, caspase-3, FasL, TGF- $\beta$, c-fos, and c-Jun as well as blocks extracellular signal-regulated kinase (ERK)-1/2 phosphorylation pathway [31,32]. Furthermore, both limonene and $\mathrm{POH}$ could possibly inhibit tumor progression through down-regulation of basal production of vascular endothelial growth factor (VEGF) in cancer cells [16]. Additionally, they also suppressed the mevalonate pathway as well as isoprenylation of small G proteins leading to tumor regression $[33,34]$.

Plants are hence a potential source of drug discovery and development of cancer chemoprevention or treatment. It has been reported that they produce secondary metabolites with antitumoral effect available for the treatment of cancer patients [35]. We found antitumoral activity with a selective cytotoxicity of human tumor epithelial cells lines such as MCF-7 (mammary) and 786-O and ACHN (renal). The viability and proliferation were significantly affected by the treatment. Meanwhile, the EOs did not show any cytotoxic effect on non-tumor human epithelial cell lines MCF10A (mammary) and HK2 (renal). More studies, however, are necessary to carry out the anti-cancer activity of EOs and also their source of biological and chemical diversity [36]. The unique and complex structures of natural products cannot be obtained easily by chemical synthesis. Interest in medicinal plant research has increased in recent years, especially for the treatment of cancer [37]. Cytotoxicity has been reported for many EOs [34]. Despite the new evidence that has been reported, very few studies have been carried out on the combination of EOs with chemotherapy drugs, (e.g., the association synergistic effect of Geraniol and 5-fluorouracil tested in both SW620 and Caco-2 human colon carcinoma cell lines [32,38].

The CA_EO showed low or no toxicity against C. elegans (Figure 6) but the LS_EO showed toxicity in all the concentrations evaluated with $100 \%$ mortality both at 24 and $48 \mathrm{~h}$. The CA_EO was toxic at $24 \mathrm{~h}$ at $50 \%$ with $100 \%$ mortality at $48 \mathrm{~h}$. At $6.25 \mathrm{mg} / \mathrm{mL}$, however, it showed toxicity at $48 \mathrm{~h}$ with 55\% mortality. Although some level of toxicity was observed, it was only at the highest concentrations, higher than those recommended for studies in C. elegans $(1 \mathrm{mg} / \mathrm{mL})$ of the authors [19]. This demonstrates that CA_EO has low or no toxicity as opposed to the high toxicity of LS_EO.

The CA_EO showed some level of toxicity at the highest concentrations (50-3.125 mg/mL) higher than those recommended for studies in C. elegans $(1 \mathrm{mg} / \mathrm{mL})$, Forno [39], demonstrating that this oil 
presented low or no toxicity. Similar to what was reported Larrazabal [19], using oils from Rica rica and Copa copa showed low toxicity in C. elegans. Other studies reported marginal toxicity of EO obtained from Amomum subulatum [40]. On the other hand, tests with LS_EO showed high toxicity in all concentrations used against $C$. elegans $(50-0.39 \mathrm{mg} / \mathrm{mL}$ ). Similarly, Enam [41] reported nematocidal activity against $C$. elegans of thymol and p-cymene, ratified by Isman [42], reported a high toxicity effect of $p$-cymene.

The limitation of this study was that the biological activity of the major monoterpenes was not determined, and it would be an interesting topic to address in future studies.

\section{Materials and Methods}

\subsection{Composition}

Gas chromatography-mass spectrometry (GC-MS) analysis was performed on a Varian gas chromatograph series 431 (Agilent Technologies, Inc., Santa Clara, CA, USA) fitted with a DB-5 ms fused silica capillary column $(30 \times 0.25 \mathrm{~mm}$; film thickness, $0.25 \mu \mathrm{m})$ using split/split-less injection and coupled to a series 220 mass detector (Agilent Technologies, Inc.). The following conditions were used: injection volume: $0.8 \mu \mathrm{L}$ with split ratio 1:80; helium as a carrier gas at $1.5 \mathrm{~mL} / \mathrm{min}$ in constant flow; injector temperature: $250{ }^{\circ} \mathrm{C}$; oven temperature: $50-260{ }^{\circ} \mathrm{C}$ at $2{ }^{\circ} \mathrm{C} / \mathrm{min}$. The mass spectra electron impact (EI+) mode was set at $70 \mathrm{eV}$, with an ion source temperature of $260^{\circ} \mathrm{C}$. The mass spectra were recorded within a range of 40-300 atomic mass units. Identification of the EO constituents was accomplished based on the following: the retention index (RI) determined with respect to a homologous series of $n$-alkanes $\left(\mathrm{C}_{5}-\mathrm{C}_{28}\right.$; PolyScience, Niles, IL, USA) under the same experimental conditions; co-injection with standards (Sigma-Aldrich) and standard isolates; identification using an MS library (NIST 05 and Wiley; NIST/EPA/NIH Mass Spectral Library with Search Program (data version NIST 11; software version $2.0 \mathrm{~g}$ ), available online at: http://www.nist.gov/srd/nist1a.cfm) and comparison with previously reported MS data [43].

\subsection{Collection Identification and Extraction}

The aerial parts of Cryptocarya alba (Molina) Looser (synonym Peumus alba Molina, vernacular name peumo), Lauraceae were collected at the beginning of the flowering season in September 2017 from Altos de Chicauma $\left(33^{\circ} 00^{\prime}-33^{\circ} 17^{\prime} \mathrm{S}\right.$ and $\left.70^{\circ} 53^{\prime}-71^{\circ} 00^{\prime} \mathrm{W}\right)$, Santiago Province, in the central region of Chile and Laurelia sempervirens Tul. (synonym Atherosperma sempervirens) were collected at the beginning of the flowering season in September 2017 from Curiñanco $\left(39^{\circ} 48^{\prime} 30^{\prime \prime} S\right.$ and $\left.73^{\circ} 14^{\prime} 30^{\prime \prime} \mathrm{W}\right)$ Valdivia, Chile.The plant was identified by Dr. Ecotoxicology Carlos Valdovinos and a voucher specimen was deposited at the Herbarium of the Facultad de Ciencias Químicas y Farmacéuticas, Universidad de Chile (CA-N $\mathrm{N}_{\mathrm{O}} .22,472 \mathrm{SQF}, \mathrm{LS}-\mathrm{N}_{\mathrm{O}}$. 22776). The EO was extracted by water distillation in a Clevenger-type apparatus. The EO was dried over and stored as previously described [40] until further analysis.

\subsection{Antioxidant Capacity}

The total polyphenol content (TPC) and the antioxidant capacity of the oils were determined by the ferric reducing antioxidant power (FRAP) and 1,1-diphenyl-2-picrylhydrazyl (DPPH) assays using Trolox (53188-07-1, Sigma-Aldrich, St. Louis, MO, USA) as a standard, according to the protocols described by [44] and adapted for Synergy ${ }^{\mathrm{TM}}$ HTX multimodal microplate reader, equipped with dual reagent injector module (BioTek Instruments, Inc., Winooski, VT, USA). All assays were performed in Corning ${ }^{\circledR}$ Costar ${ }^{\circledR}$ 96-well microplates (Corning Life Sciences., Oneonta, NY, USA).

\subsubsection{Chemical Materials}

1,1-diphenyl-2-picrylhydrazyl radical (DPPH), 2,2'-azino-bis(3-ethylbenzothiazoline-6-sulfonic acid) diammonium salt (ABTS), Folin \& Ciocalteu's phenol reagent, 2,4,6-tris-(2-pyridyl)-s-triazine 
(TPTZ), ( \pm )-6-hydroxy-2,5,7,8-tetramethylchromane-2-carboxylic acid (Trolox), potassium persulfate $\left(\mathrm{K}_{2} \mathrm{~S}_{2} \mathrm{O}_{8}\right)$, and gallic acid were purchased from Sigma-Aldrich (St. Louis, MO, USA). Sodium carbonate $\left(\mathrm{Na}_{2} \mathrm{CO}_{3}\right)$, iron (III) chloride hexahydrate $\left(\mathrm{FeCl}_{3} 6 \mathrm{H}_{2} \mathrm{O}\right)$, hydrochloric acid $(\mathrm{HCl})$, methanol $(\mathrm{MeOH})$, sodium phosphate monobasic $\left(\mathrm{NaH}_{2} \mathrm{PO}_{4}\right)$ and sodium phosphate dibasic $\left(\mathrm{Na}_{2} \mathrm{HPO}_{4}\right)$ were purchased from Merck (Darmstadt, Germany).

\subsubsection{Total Polyphenol Content (TPC) Estimation}

The TPC method was based on the 96-well microplate Folin-Ciocalteu method and adapted from [12]. A $20 \mu \mathrm{L}$ sample of the diluted EO $(500 \mu \mathrm{g} / \mathrm{mL})$ was mixed with $100 \mu \mathrm{L}$ of $10 \%(v / v)$ Folin-Ciocalteu reagent and shaken. The mixture was left for $5 \mathrm{~min}$, and then $80 \mu \mathrm{L}$ of sodium carbonate solution $(700 \mathrm{mM})$ was added, and the mixture was shaken for $1 \mathrm{~min}$. After $60 \mathrm{~min}$ at room temperature, the absorbance was measured at $765 \mathrm{~nm}$ using a microplate reader. Gallic acid dilutions $(0-1000 \mu \mathrm{g} / \mathrm{mL})$ were used as standards for calibration. The results were expressed as $\mathrm{mg}$ of gallic acid equivalent per $\mathrm{ml}$ of essential oil. All experiments were performed in triplicate.

\subsubsection{FRAP Assay}

The FRAP assay was carried out with the following method [44]. The FRAP reagent consisted of $300 \mathrm{mM}$ acetate buffer $\mathrm{pH}$ 3.6, $10 \mathrm{mM}$ 2,4,6-tris-(2-pyridyl)-s-triazine (TPTZ) solution in $40 \mathrm{mM} \mathrm{HCl}$, and $20 \mathrm{mM} \mathrm{FeCl}_{3} \cdot 6 \mathrm{H}_{2} \mathrm{O}$ aqueous solution at a ratio of 10:1:1 (v/v). The EOs were prepared at a final concentration of $500 \mu \mathrm{g} / \mathrm{mL}$. The extract solution $(10 \mu \mathrm{L})$ was mixed with $70 \mu \mathrm{L}$ of freshly prepared FRAP solution and incubated at $37^{\circ} \mathrm{C}$ for $30 \mathrm{~min}$. The absorbance of the solutions was measured at $593 \mathrm{~nm}$. Trolox was used as the standard solution to construct a calibration curve over a concentration range of $0-500 \mu \mathrm{g} / \mathrm{mL}$. The FRAP results were expressed as $\mathrm{mg}$ of Trolox equivalent per $\mathrm{mL}$ of EO. All experiments were performed in triplicate.

\subsubsection{DPPH Radical Scavenging Activity Assay}

The quantitative measurement of the EOs radical scavenging properties was carried out by the following methodology [16]. A $0.2 \mathrm{mM}$ solution of DPPH in methanol was prepared, and $70 \mu \mathrm{L}$ of this solution was added to $20 \mu \mathrm{L}$ of EO $(0-1000 \mu \mathrm{g} / \mathrm{mL})$. Trolox at concentrations of $0-1000 \mu \mathrm{g} / \mathrm{mL}$ was used as a reference antioxidant. Discoloration of reaction mixture was measured at $517 \mathrm{~nm}$ after incubation for $30 \mathrm{~min}$. The results were expressed as $\mathrm{IC}_{50}$ values (concentration of $\mathrm{EO}$ in $\mu \mathrm{g} / \mathrm{mL}$ required to inhibit $50 \%$ of DPPH radical present in solution). The analyses were carried out in triplicate.

\subsubsection{ABTS Radical-Scavenging Activity Assay}

The radical scavenging capacity of the samples for ABTS radical cation was carried out by following method. ABTS was generated by mixing a $7 \mathrm{mM}$ stock solution of ABTS in PBS at $\mathrm{pH} 7.4$ with $2.5 \mathrm{mM} \mathrm{K}_{2} \mathrm{~S}_{2} \mathrm{O}_{8}$ (final concentration) followed by storage in the dark at room temperature for $16 \mathrm{~h}$ before use. The mixture was diluted with PBS to give an absorbance of $0.700 \pm 0.02$ units at $734 \mathrm{~nm}$ using spectrophotometer. For each sample, diluted solution of the sample $(20 \mu \mathrm{L})$ was allowed to react with fresh ABTS solution $(180 \mu \mathrm{L})$, and then the absorbance was measured 6 min after initial mixing. The blank was prepared from $180 \mu \mathrm{L}$ of solution of the ABTS in PBS and $20 \mu \mathrm{L}$ of PBS. Trolox was used as a standard and the capacity of free radical scavenging was expressed by $\mathrm{IC}_{50}(\mu \mathrm{g} / \mathrm{mL})$ values calculated denote the concentration required to scavenge $50 \%$ of ABTS radicals. All measurements were performed in triplicate $[45,46]$.

\subsection{Antibacterial Activity}

\subsubsection{Chemical Materials and Antibiotics}

$\alpha$-Terpineol, $\beta$-phellandrene, and eucalyptol were purchased from Sigma Aldrich ( $99 \%$ pure), while the antibiotic cocktail DENT ${ }^{\circledR}$ (SR014E), which is selective for H. pylori (HP) growth, 
was purchased from Oxoid, USA and contained $10 \mathrm{mg} / \mathrm{mL}$ vancomycin; $5 \mathrm{mg} / \mathrm{mL}$ cefsulodin; $5 \mathrm{mg} / \mathrm{mL}$ amphotericin $B$ and $5 \mathrm{mg} / \mathrm{mL}$ trimethoprim. Other antibiotic stocks used were $100 \mathrm{mg} / \mathrm{mL}$ ampicillin and $12.5 \mathrm{mg} / \mathrm{mL}$ tetracycline, both from Sigma Aldrich (St. Louis, MO, USA).

\subsubsection{Microbial Strains}

For the microbiological studies the bacteria strains used were: 16 S. aureus (15 clinical isolates and the reference strain ATCC 25923), 16 E. coli (15 clinical isolates and the reference strain ATCC 25922) were obtained from the collection of Laboratorio de Microbiología, Departamento de Tecnología Médica, Universidad Diego Portales kindly provided by Pedro Cortés and 15 C. albicans and C. parapsilosis (ATCC 22019) (a reference strain used in genus Candida assays, kindly provided by Dr. Alvarez, Instituto de Ciencias Biomédicas, Facultad de Medicina, Universidad de Chile. The strains were grown in Mueller Hinton Agar and incubated at $37^{\circ} \mathrm{C}$.

Seven H. pylori (HP) strains were selected from a collection of clinical isolates from the Laboratorio Patogenesis Microbiana, Facultad de Medicina, Universidad Diego Portales, Santiago, Chile. The HP strains were routinely cultured on $1.5 \%$ Brucella agar (from BD, USA) supplemented with 5-7\% horse blood and DENT cocktail diluted 1:200 and were incubated for 3-7 days under microaerophilic conditions $\left(10 \% \mathrm{CO}_{2}\right)$ and $95 \%$ humidity at $37^{\circ} \mathrm{C}$. The $\mathrm{HP}$ strains were confirmed by colony morphology, Gram staining, the urease test (He-Py Test, GrupoBios, Chile) and positive PCR using primers for the H. pylori-specific hpaA gene, which has been previously described (Bergozelli et al., 2003). HP strain HPK5 was used as a pathogen reference [47,48].

\subsubsection{Agar Disk Diffusion Assay}

The agar disk diffusion technique has been widely used to assay plant extracts for antimicrobial activity. In this method, $6 \mathrm{~mm}$ sterilized filter paper disks (Whatman ${ }^{\circledR}$ No 1) were saturated with $10 \mu \mathrm{L}$ of filter-sterilized oil plant extract. The impregnated discs were then placed onto the surface of a suitable solid agar medium, such as Mueller Hinton $\mathrm{BD}^{\circledR}$. The media was pre-inoculated with test organisms. A standard inoculum size of $1 \times 10^{8} \mathrm{CFU} / \mathrm{mL}$ of bacteria was used to inoculate the diffusion plates, which is equal to the McFarland 0.5 turbidity standard. The plates were incubated overnight at $37^{\circ} \mathrm{C}$, and the diameter of the inhibition zone around each disk (diameter of inhibition zone plus diameter of the disk) was measured in millimeters. A Sensydisc was used as a positive control for Gram+ and Gram- strains Sigma Aldrich (St. Louis, MO, USA) [48].

\subsubsection{Microplate Assay}

The microdilution method was performed in ELISA plates according to instructions approved by the Clinical and Laboratory Standards Institute. For this purpose, the oil was added in 10-fold decreasing serial concentrations into Mueller Hinton broth $\mathrm{BD}^{\circledR}$. Fresh bacterial suspensions (equivalent to $1 \times 10^{8}$ bacteria $/ \mathrm{mL}$ ) were used to inoculate the microplates and were incubated as described above [48].

To enhance EO solubility, they were dissolved in 2\% (v/v) dimethyl sulfoxide (DMSO) Merck ${ }^{\circledR}$ (this amount does not affect bacterial growth) and then added to the microplates. The inoculated microplates were incubated as described above for agar plates, but for only 1 day. ELISA (Tecan) readings at $600 \mathrm{~nm}$ were recorded to calculate the MIC values as described by the Clinical and Laboratory Standards Institute [48,49] protocol. Control microplates of bacteria without the EO and without bacteria were also included in these assays. To identify significant differences between treated and untreated groups, data comparison by the ANOVA test was performed using the GraphPad Prism 5 program. 


\subsection{Cytotoxicity}

\subsubsection{Cell Lines Culture}

The human epithelial mammary cell lines MCF10A (non-tumoral) and MCF7 (tumoral) and the human epithelial renal cell lines HK-2 (non-tumoral), 786-O and ACHN (tumoral) were obtained from American Type Culture Collection (ATCC, Rockville, MD). Glioblastoma cell lines U87GM and Primary human fibroblasts. The cells were cultured in Dulbecco's Modified Eagle's F-12 Medium (DMEM-F12; Gibco, USA) supplemented with $10 \%$ fetal bovine serum (FBS; Gibco, USA) and maintained at $37^{\circ} \mathrm{C}$ in $5 \%$ of $\mathrm{CO}_{2}$ atmosphere. When the cells reach the $80 \%$ of confluence were replicated. The numbers of generations of the cell lines were about $5-10$. In vitro assays were performed in triplicate of three independent experiments for each cell line.

\subsubsection{Chemical Materials}

Trypsin-EDTA 0.5\% (Gibco, USA), PBS 1X (Gibco, USA), DMSO, crystal violet, ethanol, $\mathrm{Na}_{2} \mathrm{HPO}_{4}$, DMEM F12, FBS, MTT, HCl, were purchased from Sigma-Aldrich (St. Louis, MO, USA).

\subsubsection{Crystal Violet Proliferation Assay}

To evaluate the dose-response at given concentrations and the time-course of Eos, the cells where detached with Trypsin-EDTA $0.5 \%$ (Gibco, USA) and $5 \times 10^{3}$ cells/well were seeded and incubated in a 96-well cell plate with DMEM-F12 supplemented with 10\% FBS for $24 \mathrm{~h}$. The supernatant were removed and the cells were washed $1 \times$ with PBS 1 X (Gibco, USA), and treated with EOs extracts of CA or LS at known concentrations $(64,32,16,8,4$, or $2 \mu \mathrm{g} / \mathrm{mL})$ dissolved in culture medium (DMEM-F12 supplemented with 1\% FBS). The vehicle was DMSO 1\% dissolved in DMEM-F12, supplemented with 1\% FBS as a control treatment (the EOs are dissolved in DMSO 1\%). After 24 or $48 \mathrm{~h}$ the supernatant was discarded, the cells were washed with PBS 1X and incubated with $100 \mu \mathrm{l}$ of crystal violet (CV) solution ( $0.2 \%$ w/v in ethanol 10\%) (Gibco, USA) for $20 \mathrm{~min}$, then the CV solution was removed and $\mathrm{Na}_{2} \mathrm{HPO}_{4}(0.1 \mathrm{M}, \mathrm{pH} 4.5$, in ethanol 50:50 v/v) (SIGMA, USA), was added to elute the intra-cellular colorant. The absorbance of each sample was measured at $570 \mathrm{~nm}$. The results are shown as percentage of color intensity and normalized to cells grown in DMSO 1\% as control treatment.

\subsubsection{MTT Proliferation Assay}

To evaluate the dose-response at given concentrations of EOs, $5 \times 10^{3}$ cells/well were seeded and incubated in a 96-well cell plate with DMEM-F12 10\% FBS for $24 \mathrm{~h}$. The cells were treated with EOs extracts at known concentrations $(64,32,16 \mu \mathrm{g} / \mathrm{mL})$ dissolved in culture medium (DMEM 1\% FBS) or control medium (DMSO 1\% in DMEM 1\% FBS). After 24 or $48 \mathrm{~h}$ the supernatant was discarded and MTT solution was added to each well, according to the manufacturer's recommendation. The cells were incubated in dark at $37^{\circ} \mathrm{C}$ for $2 \mathrm{~h}$. After that, the MTT solution was removed and acidified isopropanol $(4 \%$ of $\mathrm{HCl} 1 \mathrm{~N})$ was added. The absorbance of each sample was measured at $570 \mathrm{~nm}$. The results are shown as the percentage of color intensity and normalized to cells grown in DMSO 1\% as control treatment.

\subsubsection{Statistical Analysis}

The results were analyzed by ANOVA One way for independent data with Tukey's test post-hoc. A $p<0.05$ was considered as statistically significant.

\subsection{Toxicity}

\subsubsection{Chemical Materials}

$\mathrm{NaCl}$, nematode growth medium, $\mathrm{KH}_{2} \mathrm{PO} 4, \mathrm{Na}_{2} \mathrm{HPO} 4, \mathrm{MgSO} 4, \mathrm{DMSO}$, Ethanol absolute, were purchased from Sigma-Aldrich (St. Louis, MO, USA). 


\subsubsection{Maintenance of Caenorhabditis Elegans Culture}

The N2 wild-type strain of C. elegans was used to investigate toxicity. The nematodes were maintained on nematode growth medium (NGM) agar plates, with an established layer of the E. coli OP50 strain. The plates were maintained at $20^{\circ} \mathrm{C}$ for 3 days. The gravid nematodes were collected and treated for $5 \mathrm{~min}$ in a chlorine solution $(0.45 \mathrm{~N} \mathrm{NaOH}, 2 \% \mathrm{HOCl}$ Sigma Aldrich (St. Louis, MO, USA)) to isolate eggs. The eggs were placed in plates with OP50; once hatched they were left for 3 days to obtain synchronized adult nematodes. These were collected in $\mathrm{M} 9$ saline solution $\left(1.5 \mathrm{~g} \mathrm{KH}_{2} \mathrm{PO}_{4}, 3 \mathrm{~g}\right.$ $\mathrm{Na}_{2} \mathrm{HPO}_{4}, 2.5 \mathrm{~g} \mathrm{NaCl}, 0.5 \mathrm{~mL}$ of $1 \mathrm{M} \mathrm{MgSO}_{4}$ Sigma Aldrich (St. Louis, MO, USA) and distilled water for a final volume of $500 \mathrm{~mL}$ ) [50].

\subsubsection{Test Preparation}

The CA and LS essential oils were prepared at concentrations of $0.39,0.78,1.56,3.12,6.25,12.5$, 25 and $50.0 \mathrm{mg} / \mathrm{mL}$ and placed in a final volume of $100 \mu \mathrm{L}$ in 96 -well plates. The control assays were performed with M9 and 1\% DMSO Sigma Aldrich (St. Louis, MO, USA). Ten individuals of C. elegans/well were used in each trial. The plates were incubated (incubator Binder KT) at $20{ }^{\circ} \mathrm{C}$ for 24 and $48 \mathrm{~h}$. The experiments were performed in triplicate and repeated twice. After incubation at $20^{\circ} \mathrm{C}$, all the nematodes were counted at 24 and $48 \mathrm{~h}$ to determine their survival. They were considered alive if they showed some type of motility and were considered dead when they showed no movement, either from their tail, head or pharynx, after $5 \mathrm{~s}$ of observation (Stereo Microscope Leica MZ12). The count was performed to establish the degree of mortality [51].

\section{Conclusions}

This study shows new interesting knowledge about EOs extracted using hydrodistillation in Clevenger apparatus Cryptocarya alba and Laurelia sempervirens. The chemical composition analyzed by GC-MS allowed us to determine the major components present in each species, which could be responsible for the biological activity they present, in future studies the activity of each one of them could be studied. Both EOs showed antimicrobial activity in different concentrations to different bacteria. Due to great antibacterial activity, along with the composition of EOs, we see a great potential for future usages of these oils, such as natural antimicrobials or food preservatives. Additional studies, including pharmacological, toxicological, and clinical aspects and formulation of these compounds, will be required to understand the role of some components of CA and LS_EOs to demonstrate the remarkable efficacy and safety of these EOs as antimicrobial agents. The CA and LS_EOs have important bioactive potential, cytotoxicity and toxicity, which would allow their use of active ingredients in fields such as the clinical, nutrition, cosmetics, sanitation and plaguicides, among others.

Supplementary Materials: The following are available online, Figure S1: Chromatographic GC profile of L. sempervirenes essential oil, Figure S2: Chromatographic GC profile of C. alba essential oil, Figure S3: Dose-response curve of human epithelial mammary tumor cell line MCF-7 treated with CA (peumo) and LS (laurel) EOs.

Author Contributions: Conceptualization, methodology, investigation, writing-original draft preparation, writing-review and editing, funding acquisition, M.J.L.-F., A.P. (Adrian Paredes), I.N., M.F., F.B., A.V., and J.B. Additionally J.T. and M.N., analyzed antibacterial activity in H. pylori, B.S. and J.B., analyzed GC-MS, A.P. (Alequis Pavon), G.C., K.F. analyzed citoxicity in fibroblast, C.Q., A.T. analyzed citoxicity in Glioblastoma, M.J.L.-F., A.P. (Adrian Paredes) and I.N. analyzed antioxidant activity and toxicity front C. elegans, M.F. and F.B. analyzed in epithelial mammary cell lines MCF10A (non-tumoral) and MCF7 (tumoral) and the human epithelial renal cell lines HK-2 (non-tumoral), 786-O and ACHN (tumoral), J.B. and K.F., studies the bacteria strains used were: 16 S. aureus (15 clinical isolates and the reference strain ATCC 25923), 16 E. coli (15 clinical isolates and the reference strain ATCC 25922). All authors have read and agreed to the published version of the manuscript.

Funding: This work was supported by Universidad Diego Portales [Proyecto Semilla 201521].

Acknowledgments: The authors are grateful to Mehdi Bravo for his help in English editing. Pedro Cortés TM, Facultad de Salud y Odontología, Universidad Diego Portales.

Conflicts of Interest: The authors declare no conflict of interest. 


\section{Abbreviations}

EOs: Essential Oils; MC: majority compounds; TPC: Total polyphenol content; AC: Antioxidant capacity; GC-MS: Gas chromatography-mass spectrometry; MIC: Minimum inhibitory concentration; HD: hydrodistillation; CA: Cryptocarya alba (Peumo); LS: Laurelia sempervirens (Laurel).

\section{References}

1. Mølgaard, P.; Holler, J.G.; Asar, B.; Liberna, I.; Rosenbæk, L.B.; Jebjerg, C.P.; Jørgensen, L.; Lauritzen, J.; Guzman, A.; Adsersen, A.; et al. Antimicrobial evaluation of Huilliche plant medicine used to treat wounds. J. Ethnopharmacol. 2011, 138, 219-227. [CrossRef] [PubMed]

2. Bray, F.; Ferlay, J.; Soerjomataram, I.; Siegel, R.L.; Torre, L.A.; Jemal, A. Global cancer statistics 2018: GLOBOCAN estimates of incidence and mortality worldwide for 36 cancers in 185 countries. CA Cancer J. Clin. 2018, 68, 394-424. [CrossRef] [PubMed]

3. Lesgards, J.-F.; Baldovini, N.; Vidal, N.; Pietri, S. Anticancer Activities of Essential Oils Constituents and Synergy with Conventional Therapies: A Review. Phytother. Res. 2014, 28, 1423-1446. [CrossRef] [PubMed]

4. Blowman, K.; Magalhães, M.; Lemos, M.F.L.; Cabral, C.; Pires, I.M. Anticancer Properties of Essential Oils and Other Natural Products. Evid.-Based Complement. Altern. Med. 2018, 2018, 1-12. [CrossRef]

5. Xiong, R.; Jiang, J.; Chen, Y. Cytotoxic lignans from Cryptocarya impressinervia. Nat. Prod. Res. 2019, 1-5. [CrossRef]

6. Suzuki, Y.; Saito, Y.; Goto, M.; Newman, D.J.; O’Keefe, B.R.; Lee, K.-H.; Nakagawa-Goto, K. (-)-Neocaryachine, an Antiproliferative Pavine Alkaloid from Cryptocarya laevigata, Induces DNA Double-Strand Breaks. J. Nat. Prod. 2017, 80, 220-224. [CrossRef]

7. Al-Kalaldeh, J.Z.; Abu-Dahab, R.; Afifi, F.U. Volatile oil composition and antiproliferative activity of Laurus nobilis, Origanum syriacum, Origanum vulgare, and Salvia triloba against human breast adenocarcinoma cells. Nutr. Res. 2010, 30, 271-278. [CrossRef]

8. Bittner, M.L.; Arbert, C.; E Casanueva, M.; Aguilera, M.A.; Hernandez, V.; Becerra, J. Fungistatic Activity Of Essential Oils Extracted from Peumus boldus Mol., Laureliopsis philippiana (Looser) Schodde and Laurelia sempervirens (Ruiz \& Pav.) Tul. (Chilean Monimiaceae). Chil. J. Agric. Res. 2009, 69, 30-37. [CrossRef]

9. Lorca, M.A.; Canales, C.L.; Valenzuela, C.G.; Concha, E.B.; Chait, A.B.; Navarrete, C.E.P.; Berner, C.M.B. Efectos antimicrobianos de extractos de plantas chilenas de las familias Lauraceae y Atherospermataceae. Rev. Cuba. de Plantas Med. 2012, 17, 73-83.

10. Bravo, J.; Carbonell, V.; Sepúlveda, B.; Delporte, C.; Valdovinos, C.; Martín-Hernández, R.; Higes, M. Antifungal activity of the essential oil obtained from Cryptocarya alba against infection in honey bees by Nosema ceranae. J. Invertebr. Pathol. 2017, 149, 141-147. [CrossRef]

11. Zapata, N.; Smagghe, G. Repellency and toxicity of essential oils from the leaves and bark of Laurelia sempervirens and Drimys winteri against Tribolium castaneum. Ind. Crop. Prod. 2010, 32, 405-410. [CrossRef]

12. Montes, M.; Valenzuela, L.; Wilkomirsky, T.; Sanguinetti, A.; Von Baer, D. [Chemical composition of the essential oil of Cryptocarya alba (Mol.) Looser (Lauraceae) in Chile]. Ann. Pharm. Fr. 1988, 46, 41-47. [PubMed]

13. García, L.T.; Leal, A.F.; Moreno, É.M.; Stashenko, E.E.; Arteaga, H.J. Differential anti-proliferative effect on K562 leukemia cells of Lippia alba (Verbenaceae) essential oils produced under diverse growing, collection and extraction conditions. Ind. Crop. Prod. 2017, 96, 140-148. [CrossRef]

14. Jiao, J.; Fu, Y.-J.; Zu, Y.; Luo, M.; Wang, W.; Zhang, L.; Li, J. Enzyme-assisted microwave hydro-distillation essential oil from Fructus forsythia, chemical constituents, and its antimicrobial and antioxidant activities. Food Chem. 2012, 134, 235-243. [CrossRef]

15. Damasceno, C.S.B.; Higaki, N.T.F.; Dias, J.D.F.G.; Miguel, M.D.; Miguel, O.G. Chemical Composition and Biological Activities of Essential Oils in the Family Lauraceae: A Systematic Review of the Literature. Planta Med. 2019, 85, 1054-1072. [CrossRef] [PubMed]

16. Sharifi-Rad, J.; Sureda, A.; Tenore, G.C.; Daglia, M.; Sharifi-Rad, M.; Valussi, M.; Tundis, R.; Sharifi-Rad, M.; Loizzo, M.R.; Ademiluyi, A.O.; et al. Biological Activities of Essential Oils: From Plant Chemoecology to Traditional Healing Systems. Molecules 2017, 22, 70. [CrossRef]

17. Amorati, R.; Foti., M.C.; Valgimigli, L. Antioxidant Activity of Essential Oils. J. Agric. Food Chem. 2013, 61, 10835-10847. [CrossRef] 
18. Larrazabal-Fuentes, M.; Palma, J.; Paredes, A.; Mercado, A.; Neira, I.; Lizama, C.; Sepulveda, B.; Bravo, J. Chemical composition, antioxidant capacity, toxicity and antibacterial activity of the essential oils from Acantholippia deserticola (Phil.) Moldenke (Rica rica) and Artemisia copa Phil. (Copa copa) extracted by microwave-assisted hydrodistillation. Ind. Crop. Prod. 2019, 142, 111830. [CrossRef]

19. Miguel, M.G. Antioxidant activity of medicinal and aromatic plants. A review. Flavour Fragr. J. 2010, 25, 291-312. [CrossRef]

20. Memariani, Z.; Sharifzadeh, M.; Bozorgi, M.; Hajimahmoodi, M.; Farzaei, M.H.; Gholami, M.; Siavoshi, F.; Saniee, P. Protective effect of essential oil of Pistacia atlantica Desf. on peptic ulcer: Role of $\alpha$-pinene. J. Tradit. Chin. Med. 2017, 37, 57-63. [CrossRef]

21. Edris, A.E. Pharmaceutical and therapeutic Potentials of essential oils and their individual volatile constituents: A review. Phytother. Res. 2007, 21, 308-323. [CrossRef] [PubMed]

22. Raut, J.S.; Karuppayil, S.M. A status review on the medicinal properties of essential oils. Ind. Crop. Prod. 2014, 62, 250-264. [CrossRef]

23. Bergonzelli, G.; Donnicola, D.; Porta, N.; E Corthésy-Theulaz, I. Essential oils as components of a diet-based approach to management of Helicobacter infection. Antimicrob. Agents Chemother. 2003, 47, 3240-3246. [CrossRef] [PubMed]

24. Ultee, A.; Bennik, M.H.J.; Moezelaar, R. The Phenolic Hydroxyl Group of Carvacrol Is Essential for Action against the Food-Borne Pathogen Bacillus cereus. Appl. Environ. Microbiol. 2002, 68, 1561-1568. [CrossRef] [PubMed]

25. Burt, S. Essential oils: Their antibacterial properties and potential applications in foods-A review. Int. J. Food Microbiol. 2004, 94, 223-253. [CrossRef]

26. Ohno, T.; Kita, M.; Yamaoka, Y.; Imamura, S.; Yamamoto, T.; Mitsufuji, S.; Kodama, T.; Kashima, K.; Imanishi, J. Antimicrobial Activity of Essential Oils against Helicobacter pylori. Helicobacter 2003, 8, 207-215. [CrossRef]

27. Benites, J.; Moiteiro, C.; Miguel, G.; Rojo, L.E.; López, J.; Venâncio, F.; Ramalho, L.; Feio, S.; Dandlen, S.; Casanova, H.; et al. Composition And Biological Activity Of The Essential Oil Of Peruvian Lantana Camara. J. Chil. Chem. Soc. 2009, 54, 379-384. [CrossRef]

28. Zapata, N.; Lognay, G.; Smagghe, G. Bioactivity of essential oils from leaves and bark of Laurelia sempervirens and Drimys winteri against Acyrthosiphon pisum. Pest. Manag. Sci. 2010, 66, 1324-1331. [CrossRef]

29. Feoktistova, M.; Geserick, P.; Leverkus, M. Crystal Violet Assay for Determining Viability of Cultured Cells. Cold Spring Harb. Protoc. 2016, 2016, 087379. [CrossRef]

30. Bayala, B.; Bassole, I.H.; Scifo, R.; Gnoula, C.; Morel, L.; Lobaccaro, J.-M.A.; Simporé, J. Anticancer activity of essential oils and their chemical components-A review. Am. J. Cancer Res. 2014, 4, 591-607.

31. Carnesecchi, S.; Bras-Gonçalves, R.; Bradaia, A.; Zeisel, M.; Gossé, F.; Poupon, M.-F.; Raul, F. Geraniol, a component of plant essential oils, modulates DNA synthesis and potentiates 5-fluorouracil efficacy on human colon tumor xenografts. Cancer Lett. 2004, 215, 53-59. [CrossRef] [PubMed]

32. Yu, X.; Lin, H.; Wang, Y.; Lv, W.; Zhang, S.; Qian, Y.; Deng, X.; Feng, N.; Yu, H.; Qian, B.-Y. D-limonene exhibits antitumor activity by inducing autophagy and apoptosis in lung cancer. OncoTargets Ther. 2018, 11, 1833-1847. [CrossRef] [PubMed]

33. Jia, S.-S.; Xi, G.-P.; Zhang, M.; Chen, Y.-B.; Lei, B.; Dong, X.-S.; Yang, Y.-M. Induction of apoptosis by D-limonene is mediated by inactivation of Akt in LS174T human colon cancer cells. Oncol. Rep. 2012, 29, 349-354. [CrossRef] [PubMed]

34. Manuele, M.G.; Arcos, M.L.B.; Davicino, R.; Ferraro, G.; Cremaschi, G.; Anesini, C. Limonene Exerts Antiproliferative Effects and Increases Nitric Oxide Levels on a Lymphoma Cell Line by Dual Mechanism of the ERK Pathway: Relationship with Oxidative Stress. Cancer Investig. 2009, 28, 135-145. [CrossRef] [PubMed]

35. Chaudhary, S.; Siddiqui, M.; Athar, M.; Alam, M.S. d-Limonene modulates inflammation, oxidative stress and Ras-ERK pathway to inhibit murine skin tumorigenesis. Hum. Exp. Toxicol. 2012, 31, 798-811. [CrossRef] [PubMed]

36. Mo, H.; Elson, C.E. Studies of the Isoprenoid-Mediated Inhibition of Mevalonate Synthesis Applied to Cancer Chemotherapy and Chemoprevention. Exp. Biol. Med. 2004, 229, 567-585. [CrossRef] [PubMed]

37. A Ariazi, E.; Satomi, Y.; Ellis, M.J.; Haag, J.D.; Shi, W.; A Sattler, C.; Gould, M.N. Activation of the transforming growth factor beta signaling pathway and induction of cytostasis and apoptosis in mammary carcinomas treated with the anticancer agent perillyl alcohol. Cancer Res. 1999, 59, 1917-1928. 
38. Yu, J.Q.; Liao, Z.X.; Cai, X.Q.; Lei, J.C.; Zou, G.L. Composition, antimicrobial activity and cytotoxicity of essential oils from Aristolochia mollissima. Environ. Toxicol. Pharmacol. 2007, 23, 162-167. [CrossRef]

39. Forno, A.H.D.; Câmara, D.; Parise, B.; Rodrigues, C.F.; Soares, J.J.; Wagner, R.; Ribeiro, S.R.; Folmer, V.; Puntel, R.L.; Haas, S.E.; et al. Antioxidant and lipid lowering effects of dried fruits oil extract of Pterodon emarginatusin Caenorhabditis elegans. Arab. J. Chem. 2019, 12, 4131-4141. [CrossRef]

40. Satyal, P.; Dosoky, N.S.; Kincer, B.L.; Setzer, W.N. Chemical Compositions and Biological Activities of Amomum subulatum Essential Oils from Nepal. Nat. Prod. Commun. 2012, 7, 1233-1236. [CrossRef]

41. Lei, J.; Leser, M.; Enan, E. Nematicidal activity of two monoterpenoids and SER-2 tyramine receptor of Caenorhabditis elegans. Biochem. Pharmacol. 2010, 79, 1062-1071. [CrossRef] [PubMed]

42. Khanavi, M.; Laghaei, P.; Isman, M.B. Essential oil composition of three native Persian plants and their inhibitory effects in the cabbage looper, Trichoplusia ni. J. Asia-Pacific Èntomol. 2017, 20, 1234-1240. [CrossRef]

43. Sparkman, O.D. Identification of essential oil components by gas chromatography/quadrupole mass spectroscopy Robert P. Adams. J. Am. Soc. Mass Spectrom. 2005, 16, 1902-1903. [CrossRef]

44. Akter, K.; Barnes, E.C.; Loa-Kum-Cheung, W.L.; Yin, P.; Kichu, M.; Brophy, J.J.; Barrow, R.A.; Imchen, I.; Vemulpad, S.R.; Jamie, J. Antimicrobial and antioxidant activity and chemical characterisation of Erythrina stricta Roxb. (Fabaceae). J. Ethnopharmacol. 2016, 185, 171-181. [CrossRef] [PubMed]

45. Mathew, M.; Subramanian, S. In Vitro Screening for Anti-Cholinesterase and Antioxidant Activity of Methanolic Extracts of Ayurvedic Medicinal Plants Used for Cognitive Disorders. PLoS ONE 2014, 9, e86804. [CrossRef] [PubMed]

46. Horvathova, E.; Navarova, J.; Galova, E.; Sevcovicova, A.; Chodakova, L.; Snahnicanova, Z.; Melusova, M.; Kozics, K.; Slamenova, D. Assessment of Antioxidative, Chelating, and DNA-Protective Effects of Selected Essential Oil Components (Eugenol, Carvacrol, Thymol, Borneol, Eucalyptol) of Plants and IntactRosmarinus officinalisOil. J. Agric. Food Chem. 2014, 62, 6632-6639. [CrossRef] [PubMed]

47. Petrelli, R.; Orsomando, G.; Sorci, L.; Maggi, F.; Ranjbarian, F.; Nya, P.C.B.; Petrelli, D.; Vitali, L.A.; Lupidi, G.; Quassinti, L.; et al. Biological Activities of the Essential Oil from Erigeron floribundus. Molecules 2016, 21, 1065. [CrossRef]

48. Jones, R. NCCLS guidelines: Revised performance standards for antimicrobial disk susceptibility tests. Antimicrob. Newsl. 1984, 1, 64-65. [CrossRef]

49. Morcillo, N.; Di Giulio, B.; Testani, B.; Pontino, M.; Chirico, C.; Dolmann, A. A microplate indicator-based method for determining the susceptibility of multidrug-resistant Mycobacterium tuberculosis to antimicrobial agents. Int. J. Tuberc. Lung Dis. 2004, 8, 253-259.

50. Brenner, S. The genetics of caenorhabditis elegans. Genetics 1974, 77, 71-94.

51. Skantar, A.M.; Agama, K.; Meyer, S.L.F.; Carta, L.K.; Vinyard, B.T. Effects of Geldanamycin on Hatching and Juvenile Motility in Caenorhabditis elegans and Heterodera glycines. J. Chem. Ecol. 2005, 31, 2481-2491. [CrossRef] [PubMed]

Sample Availability: Not available.

Publisher's Note: MDPI stays neutral with regard to jurisdictional claims in published maps and institutional affiliations.

(C) 2020 by the authors. Licensee MDPI, Basel, Switzerland. This article is an open access article distributed under the terms and conditions of the Creative Commons Attribution (CC BY) license (http://creativecommons.org/licenses/by/4.0/). 